\title{
New katydids of the genus Asiopblugis Gor. (Orthoptera: Tettigoniidae: Meconematinae) from Singapore and Malaysia
}

\author{
Новые кузнечики рода Asiopblugis Gor. (Orthoptera: \\ Tettigoniidae: Meconematinae) из Сингапура и Малайзии
}

\author{
Andrej V. Gorochov ${ }^{1} \&$ Tan Ming Kai ${ }^{2}$ \\ A.B. Горохов, Тан Мин Кай
}

\begin{abstract}
${ }^{1}$ Zoological Institute, Russian Academy of Sciences, Universitetskaya nab. 1, St.-Petersburg 199034, Russia. E-mail: orthopt@zin.ru Зоологический институт РАН, Университетская наб. 1, Санкт-Петербург 199034, Россия.

${ }^{2}$ Department of Biological Sciences, National University of Singapore, 14 Science Drive 4, Singapore 117543, Republic of Singapore. E-mail: tmk1990@hotmail.com
\end{abstract}

KEY WORDS: Asiophlugis, Meconematinae, Tettigoniidae, Orthoptera, new taxa, Malaysia, Singapore.

КЛЮЧЕВЫЕ СЛОВА: Asiophlugis, Meconematinae, Tettigoniidae, Orthoptera, новые таксоны, Малайзия, Сингапур.

ABSTRACT. Two new species and a new subspecies (Asiophlugis temasek sp.n. from Singapore, A. $t$. tioman subsp.n. from Malaysian part of Malacca, and A. trusmadi sp.n. from Malaysian part of Borneo) are described. Phlugis thai Helfert et Sanger, 1998 is added to the genus Asiophlugis. Ph. thaumasia Hebard, 1922, Ph. borneoensis Jin, 1993, Ph. dubia Karny, 1907, and Ph. philippina Jin, 1993 are included in Asiophlugis under question.

РЕЗЮМЕ. Описаны два новых вида и новый подвид: Asiophlugis temasek sp.n. из Сингапура, A.t. tioman subsp.n. из малазийской части Малакки и $A$. trusmadi sp.n. из малазийской части Борнео. Phlugis thai Helfert et Sanger, 1998 перенесен в род Asiophlugis. Ph. thaumasia Hebard, 1922, Ph. borneoensis Jin, 1993, Ph. dubia Karny, 1907 и Ph. philippina Jin, 1993 предположительно относятся к Asiophlugis.

\section{Introduction}

The genus Asiophlugis was described by Gorochov [1998] for three Indo-Malayan species: A. rete Gorochov, 1998 from environs of Taman Negara National Park in Malaysian part of Malacca (type species); $A$. malacca Gorochov, 1998 from environs of Jerantut Town in the same state of Malaysia; A. sulawesi (Jin, 1993) from Sulawesi, originally described in the genus Phlugis Stål. Asiophlugis differs from all the other genera of the tribe Phlugidini in the more or less simple last abdominal tergite of male, comparatively short male genital plate provided with a pair of normal styles, and characteristic structure of male cerci having as the large and elongate lobe-like or finger-like most part of these cerci as the small hook-like or spine-like process at their base (Figs 1-4, 7-10, 13-14).

In the above-mentioned paper, possible belonging of the other Indo-Malayan representatives, originally included in Phlugis, to this genus is supposed. Now Phlugis thai Helfert et Sanger, 1998 from Thailand is added to Asiophlugis; A thai comb. n. is very similar to $A$. rete, but it probably has the less curved small process at the base of male cerci and wider space between styles of male genital plate [Helfert \& Sanger, 1998: Fig. 4b]. However for all the other Indo-Malayan species, presence (or absence) of any small process at the base of male cerci is not indicated (Ph. thaumasia Hebard, 1922 from Singapore; Ph. borneoensis Jin, 1993 from Kinabalu Mt. in Borneo), or male is unknown ( $P h$. dubia Karny, 1907 from Borneo; Ph. philippina Jin, 1993 from the Philippines); these species are in need of an additional study, and they are here included in Asiophlugis under question because it is indubitable that they don't belong to the Neotropical genus Phlugis.

\section{Asiophlugis temasek Gorochov et Tan, sp.n.}

Figs 1-9; 11.

MATERIAL. HOLOTYPE: $\sigma^{7}$, Singapore, Bukit Timah Nature Reserve, along main road Hindhede Drive, secondary forest, 13.XI.2010, M. K. Tan. PARATYPES: Singapore: $10^{7}, 1$, same reserve as for holotype, but Dairy Farm Loop, 10.XII.2010, M. K. Tan \& M. R. B. Ismail; $100^{7} O^{7}, 3$ 우, same reserve, 10.XII.197230.VI.1985, D. H. Murphy; $2 \sigma^{7} \sigma^{7}$, MacRitchie Reservoir Catchment Area, along Venus Trail and MacRitchie Nature Trail, secondary forest, 8.X-1.XI.2010, M. K. Tan \& M. R. B. Ismail; $10^{7}$, same area, but Sime Road forest, 5.IV.1975, D. H. Murphy. Holotype and paratypes in Zoological Reference Collection, Raffles Museum of Biodiversity Research, National University of Singapore.

DESCRIPTION. Male. General appearance typical of this genus [see Gorochov, 1998]. Coloration uniformly greenish, but with light brown both antennal flagellum and apical 

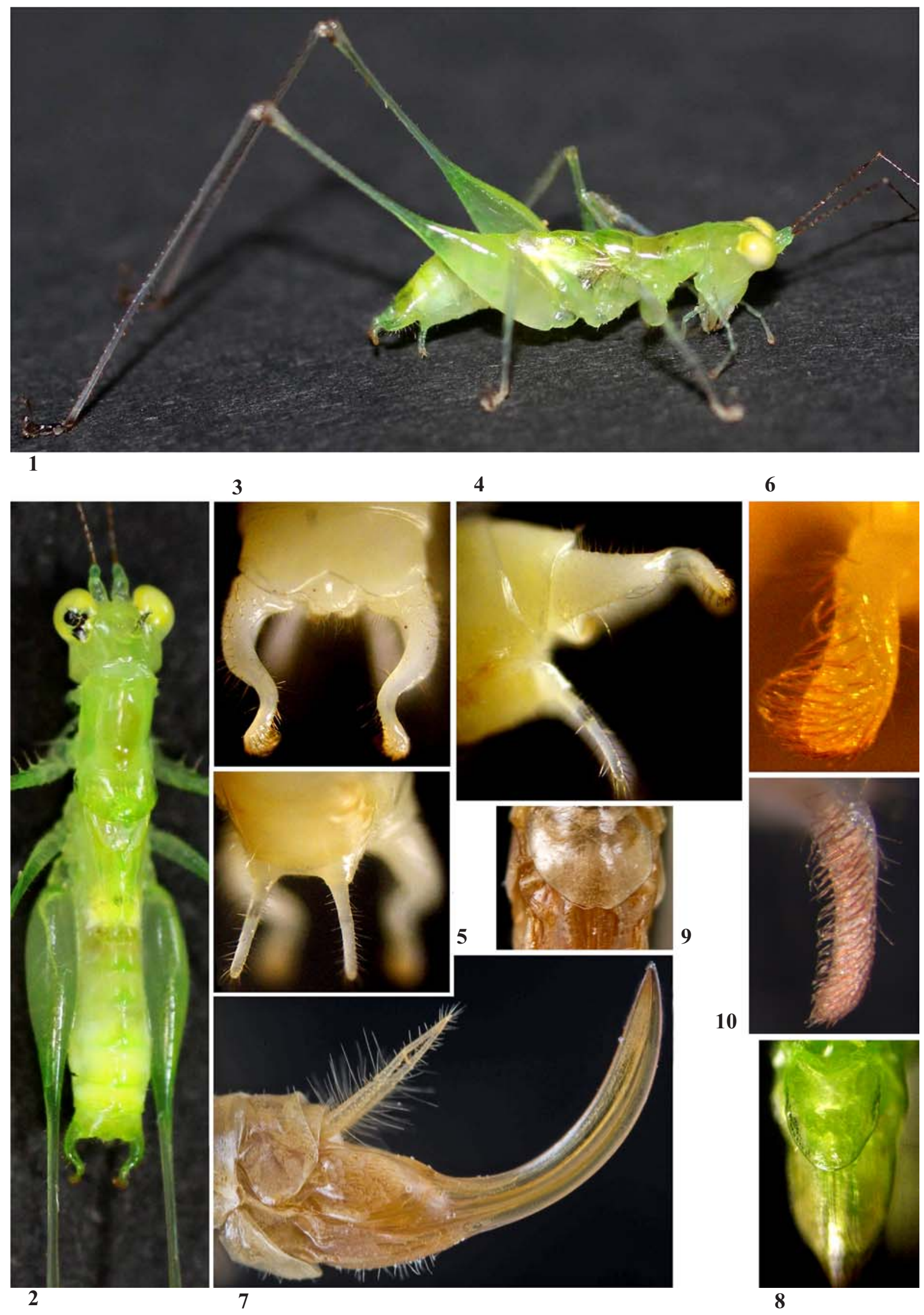
segments of palpi as well as with dark brown hind tarsi. Eyes very large, almost globular, slightly longitudinally elongate; antennal cavities contacting with each other; rostral tubercles absent; face high, oblique and hardly concave in profile. Pronotum long, with moderately elevated hind lobe having rounded hind edge and covering almost two-third of tegminal stridulatory apparatus; this lobe approximately $0.33-0.35$ times as long as pronotum; thoracic venter with only a pair of acute spines on mesosternum; these spines slightly longer than distance between their apices. Fore coxae with very long and thin spine; fore femora and fore tibiae with four long and thin spines on both ventral edges (three proximal inner tibial spines very long); middle legs unarmed; hind legs with only moderately numerous small spinules on both dorsal edges of tibia. Tegmina reaching posterior part of forth abdominal tergite; stridulatory vein as in Fig. 11; hind wings shorter than tegmina, completely covered by them. Last abdominal tergite simple, but its hind part with rather wide (but not very deep) triangular median notch; epiproct simple, weakly transverse, almost equal to above-mentioned notch in width, and with narrowly rounded apex; cerci (Figs 3-4, 6) strongly sinuate, with arcuate and almost cylindrical proximal half, with narrow and moderately lamellar distal part (this part distinctly curved downwards and provided with numerous setae on distal half and small rounded widening at apex: Fig. 6 ), and with strongly curved (hook-like) small process at base (Fig. 4); genital plate with long styles and almost straight hind edge between them (Fig. 5); genitalia membranous.

Female. Coloration and structure of body parts (excepting sexual ones) as in male. Last abdominal tergite and epiproct similar to those of male, but clearly smaller and without notch in hind part of this tergite; cerci simple and thin; genital plate slightly elongate and with rather wide and rounded hind part which sometimes hardly emarginate at apex (Figs 8-9) ; ovipositor as in Fig. 7.

LENGTH (in mm). Body: male 10.1-11.9, female 10.8 12.5; pronotum: male 3.1-3.5, female 2.9-3.3; tegmina: male 3.0-3.4, female 2.7-3.1; hind femora: male 10.6-11.4, female 10.9-11.4; ovipositor: 3.4-3.8.

COMPARISON. The new species differs from $A$. rete, $A$. thai, A.? borneoensis and A.? philippina by the male cerci clearly arcuate in proximal half and with the distal part distinctly curved downwards. From $A$. malacca, $A$. sulawesi, A.? thaumasia and A.? dubia, the new species differs in the much shorter wings.

ETYMOLOGY. The species is named after Temasek, an old name of Singapore.

\section{Asiophlugis temasek tioman Gorochov, subsp.n.} Figs 10; 12-17.

MATERIAL. HOLOTYPE: $\sigma^{7}$, Malaysia, Malacca, Pahang State, Tioman I. (not far from Mersing City in Johor State), environs of vill. Juara on eastern coast, primary forest, 6-14.IV.2010, A. Gorochov, M. Berezin, E. Tkatsheva. PARATYPES: 4 우, same data as for holotype. Holotype and paratypes in Zoological Institute, Russian Academy of Sciences, St.-Petersburg.

DESCRIPTION. Male. Coloration and structure of body parts very similar to those of male of nominotypical subspe-

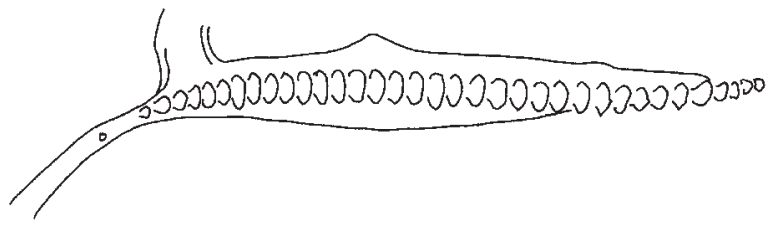

Fig. 11. Asiophlugis temasek temasek (male, paratype), stridulatory vein from below.

Рис. 11. Asiophlugis temasek temasek (самец, паратип), стридуляционная жилка снизу.

cies, but distinguished by following characters: palpi uniformly greenish; tegmina reaching base of fifth abdominal tergite; distal (curved downwards) part of cerci somewhat longer, with numerous setae on both (proximal and distal) halves of this part and without widening at its apex (Figs 10; $12,14,15)$; genital plate with slightly wider area between styles (Fig. 13).

Female. Coloration and structure of body very similar to those of female of A. t. temasek, but ovipositor somewhat longer, and genital plate with rather large median notch (Figs 16-17).

LENGTH (in mm). Body: male 11.7, female 12.5-13.0; pronotum: male 3.7, female 3.1-3.3; tegmina: male 3.5, female 3.1-3.2; hind femora: male 12.0, female 11.6-11.8; ovipositor 4.8-5.0.

COMPARISON. Differences of the new subspecies from nominotypical one are listed above, in the description of $A$. $t$. tioman.

\section{Asiophlugis trusmadi Gorochov, sp.n. Figs 18-23}

MATERIAL. HOLOTYPE: $\bigcirc^{7}$, Malaysia, Borneo, Sabah State, Trus Madi Mt., $\sim 1000 \mathrm{~m}$, partly primary / partly secondary forest, 13-25.V.2007, A. Gorochov. PARATYPES: 2 o $^{7}, 4$ 우, same data as for holotype. Holotype and paratypes in Zoological Institute, Russian Academy of Sciences, St.-Petersburg.

DESCRIPTION. Male (holotype). Coloration and structure of body parts similar to those of $A$. $t$. tioman, but distinguished by following features: eyes brownish; hind lobe of pronotum slightly elevated and covering almost half of tegminal stridulatory apparatus; this lobe approximately 0.3 times as long as pronotum; spines of thoracic mesosternum with narrowly rounded apex; these spines slightly shorter than distance between their apices; fore femora with three spines on both ventral edges; fore tibiae with five spines on both ventral edges (four inner of them very long); tegmina reaching base of last abdominal tergite; hind wings somewhat longer, reaching distal third of cerci; epiproct triangular, but its distal half curved downwards and with almost acute apex; cerci almost finger-like (completely cylindrical), but slightly sinuate, with distal part very weakly curved downwards and with rather short, acute and slightly arcuate (almost spine-like) small process at base; genital plate with moderately short styles and short rounded notch between them (Figs 18-21).

VARIATIONS. Other males distinguished from holotype only by lighter (yellowish) eyes.

Figs 1-10. Asiophlugis temasek sp.n.: 1-9 - Asiophlugis t. temasek; 10 - A. t. tioman ssp.n.; 1 - habitus; 2 - body; $3-4,7$ abdominal apex; 5, 9 - hind half of genital plate; 6,10 - distal part of cercus; 8 - genital plate and base of ovipositor; $2-3$ - above; 1 , 4, 7 - side view; 6, 10 - above and slightly from behind; 5, 8-9 - below; 1-6, 10 - males; 7-9 - females; 2-6 - holotype.

Рис. 1-10. Asiophlugis temasek sp.n.: 1-9 - Asiophlugis t. temasek; 10 - A. t. tioman ssp.n.; 1 - общий вид; 2 - тело; 3-4, 7 вершина брюшка; 5, 9 - задняя половина генитальной пластинки; 6,10 - дистальная часть церка; 8 - генитальная пластинка и основание яйцеклада; 2-3 - сверху; 1, 4, 7- сбоку; 6, 10 - сверху и слегка сзади; 5, 8-9 - снизу; 1-6, 10 - самцы; 7-9 - самки; 2-6 - голотип. 


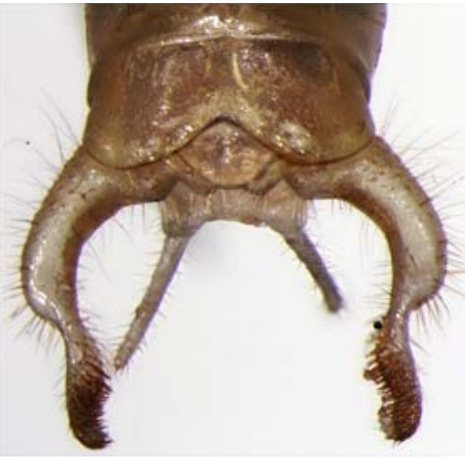

12

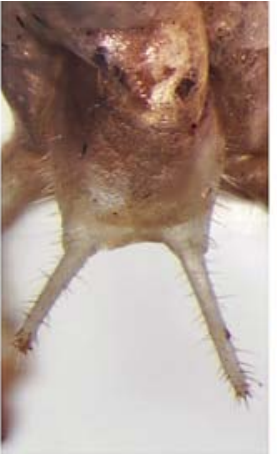

13

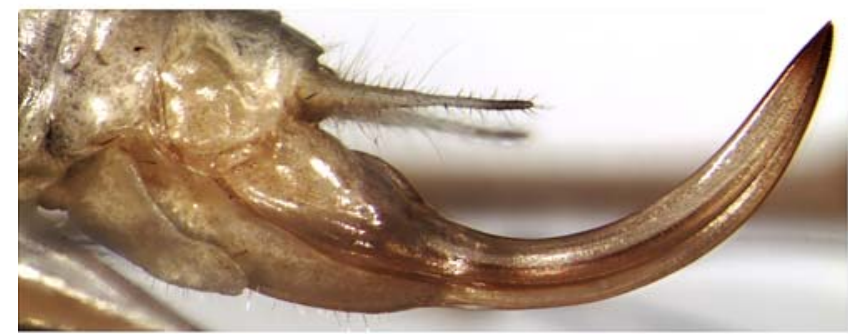

16

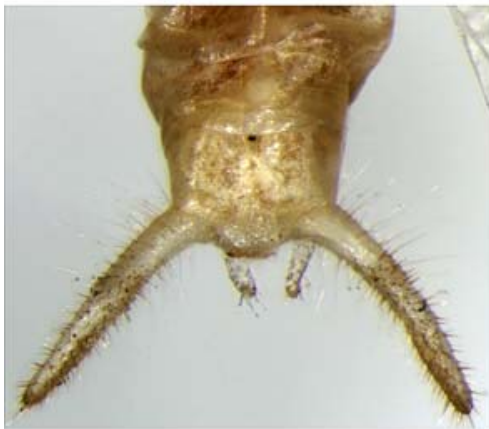

18
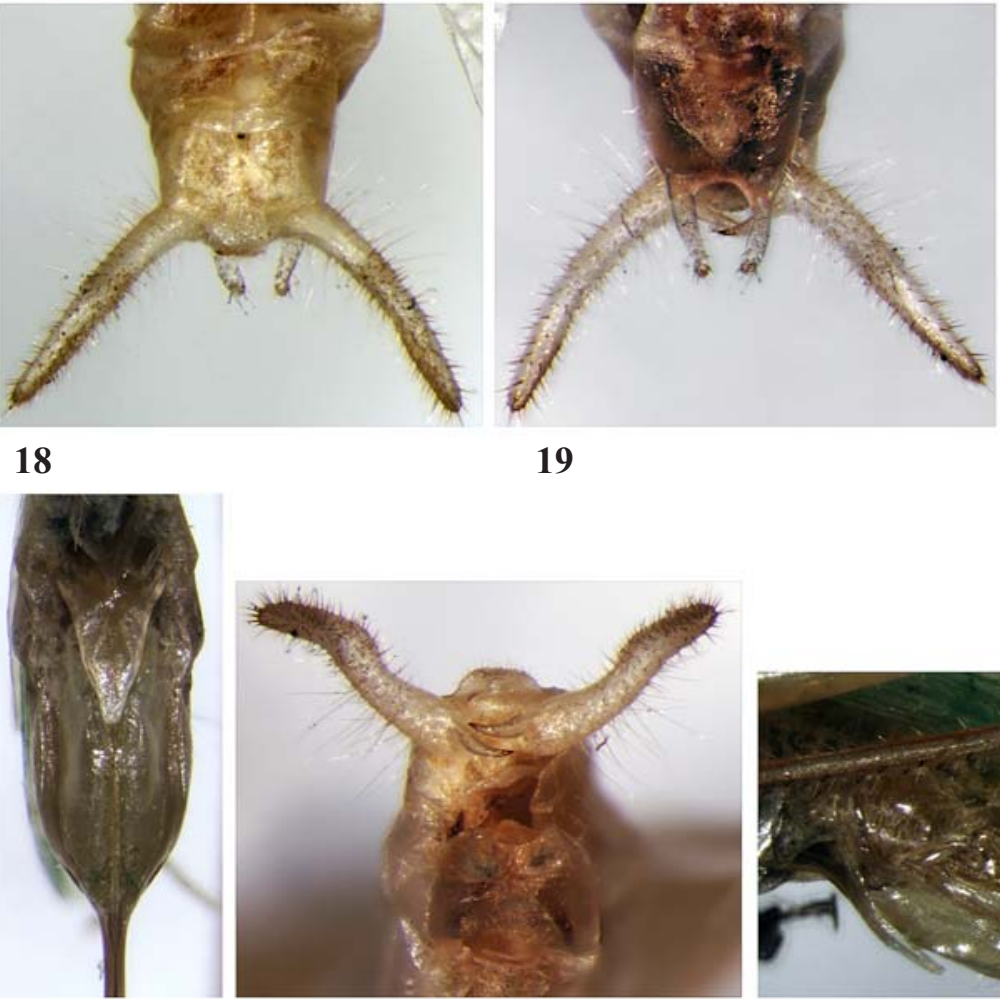

23

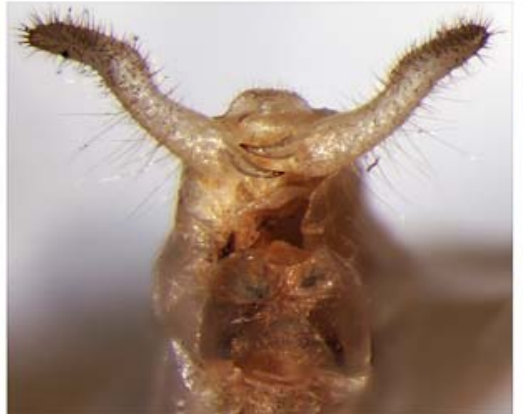

21

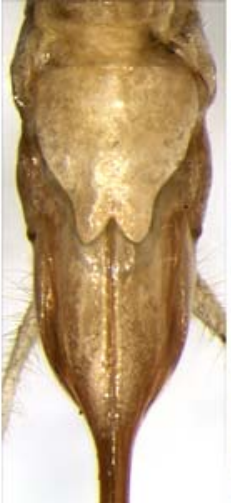

17

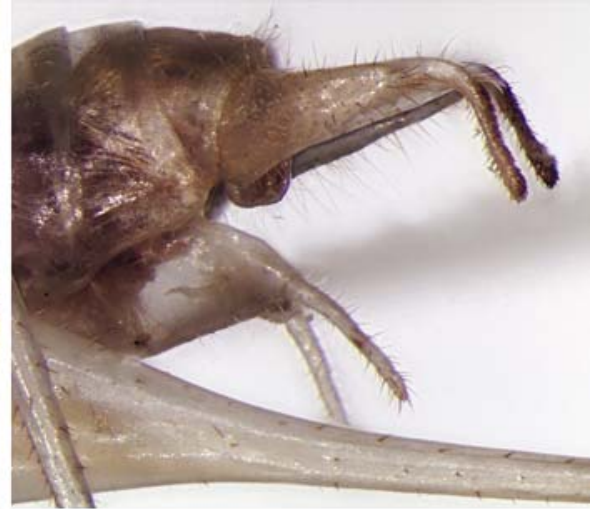

14

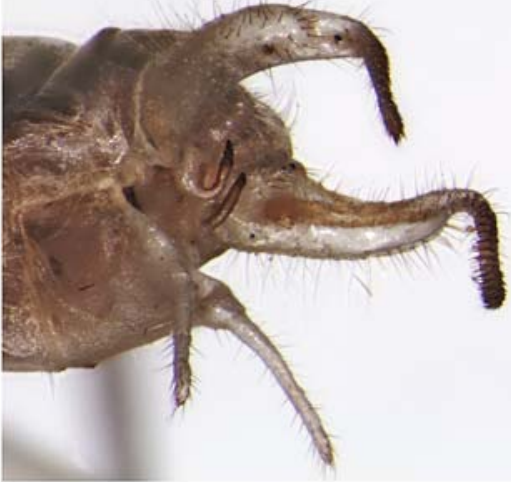

15

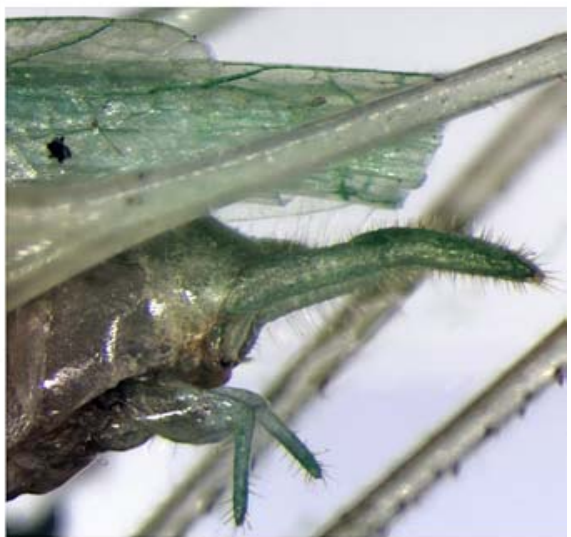

20

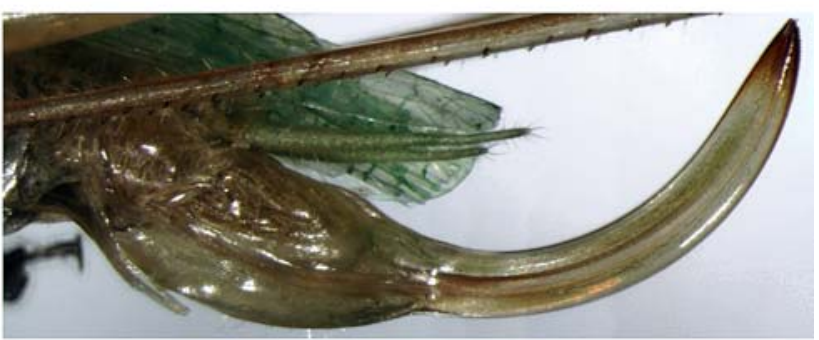

22

Figs 12-23. Asiophlugis spp: 12-17 - A. temasek tioman ssp.n.; 18-21 - A. trusmadi sp.n.; 12, 14-16, 18-22 - abdominal apex; 13 - genital plate; 17, 23 - genital plate and base of ovipositor; 12, 18 - above; 13 17, 19, 23 — below; 14, 16, 20, 22 — side; 15 — side and slightly from below; 21 - behind and slightly from below; 12-15, 18-21- males; 15-17, 22-23 - females; 18-21 - holotype.

Рис. 12-23. Asiophlugis spp: 12-17 - A. temasek tioman ssp.n.; 18-21 - A. trusmadi sp.n.; 12, 14-16, 18-22 - вершина брюшка; 13 - генитальная пластинка; 17, 23 - генитальная пластинка и основание яйцеклада; 12,18 - сверху; 13 17, 19, 23 — снизу; 14, 16, 20,22 - сбоку; 15 - сбоку и слегка снизу; 21 - сзади и слегка снизу; 12-15, 18-21- самцы; 15-17, 22-23 - самки; 18-21 - голотип. 
Female. General appearance as in male. Last abdominal tergite, epiproct and cerci similar to those of A. tioman, however genital plate with very narrow and rounded apical part (Fig. 23); ovipositor as in Fig. 22.

LENGTH (in mm). Body: male 8.0-11.5, female 9.011.7; body with wings: male $11.2-12.5$, female $12.5-13.5$; pronotum: male 3.0-3.2, female 3.0-3.3; tegmina: male 6.97.3, female 7.8-8.2; hind femora: male 9.7-10.6, female 10.5-11.2; ovipositor 4.9-5.1.

COMPARISON. The new species differs from $\mathrm{A}$. sulawesi in the male anal plate not bilobed and male cerci not lamellar; from A.? thaumasia, in the male cerci not Sshaped in profile and with the cylindrical (not lamellate) distal two-thirds; from A.? dubia, in the not emarginated apex of female genital plate. From $A$. rete, $A$. thai, $A$. temasek, A.? borneoensis and A.? philippina, the new species is distinguished by the much longer wings; additionally from $A$. rete, $A$. thai, A. temasek and A.? borneoensis, by the male cerci clearly narrower (if to see from above) or less strongly curved, as well as from A.? philippina, in the much longer spine of fore coxae.
ACKNOWLEDGEMENTS. The authors are thankful to Dr. T. M. Leong, R. W. J. Ngiam, M. R. B. Ismail, M. V. Berezin and E. Yu. Tkatcheva for their help in the material collecting, Dr. H. H. Tan, for the specimen photographing, and H. K. Lua (curator of Zoological Reference Collection), for the permission to study the material from Raffles Museum of Biodiversity Research. The authors thank the National Parks Board (Singapore) for granting the research permit to the Central Catchment Nature Reserve and Bukit Timah Nature Reserve (NP/RP10-073). This work is supported by the Russian Foundation for Basic Research (grant No. 1004-00682a) and by the Presidium of the Russian Academy of Sciences (Programme "Biosphere Origin and Evolution").

\section{References}

Gorochov A.V. 1998. New and little known Meconematinae of the tribes Meconematini and Phlugidini (Orthoptera: Tettigoniidae) // Zoosyst. Ross. Vol.7. No.1. P.101-131.

Helfert B., Sanger K. 1998. Phlugis thai sp.n., a new Phlugidini (Insecta: Ensifera, Tettigoniidae, Meconematinae) from Thailand // Ann. Naturhist. Mus. Wien. Bd.100. Dezember. S.61-68. 